\title{
PERANCANGAN SISTEM KLASIFIKASI UDANG BERACUN PADA JENIS UDANG TENGGEK MENGGUNAKAN METODE K-NEAREST NEIGHBOR (K-NN).
}

\author{
Lisa Afrinanda ${ }^{1}$, Ilyas ${ }^{2}$ \\ 1,2Program Studi Sistem Informasi, Universitas Islam Indragiri, Tembilahan \\ Email: lisaafrinanda08@gmail.com (korespondensi)
}

\begin{abstract}
Shrimp is one of the seafood which is nutrient-rich needed by the body. However, due to the frequent case of the infected Tenggek-shrimp appeared, it makes people beware to consume it. The classification of Tenggek-shrimp by using image processing of the computer be able to classify the types of shrimp whether poisonous or not. The data mining techniques can be used to classify shrimp based on RGB colors (red, green, blue) and texture (energy, contrast, correlation, homogeneity). The class of Tenggek-shrimp is divided into two, The fresh Tenggek-shrimps that are caught naturally (Class $A$ ) and the poisoned Tenggek-shrimps that are caught by using the poison (Class $B$ ). The method used in this study is $K$-Nearest Neighbor $(K-N N)$. This classification system is expected to help the people in selecting good and safe Tenggek-shrimp for consumption. Based on the evaluation results using the holdout method, obtained an average accuracy of $63 \%$ with an accuracy of identification of toxic tenggek shrimp of $71.66 \%$, and the accuracy of identification of natural fresh shrimp is about $60 \%$.
\end{abstract}

Keywords: Shrimp, Classification, K-Nearest Neighbor, RGB, Texture.

\begin{abstract}
Abstrak
Udang merupakan salah satu makanan laut yang yang kaya akan nutrisi penting yang dibutuhkan oleh tubuh, Akan tetapi, di karenakan sering munculnya kasus udang tenggek yang terinfeksi racun membuat masyarakat harus lebih berhati-hati untuk mengkonsumsinya. Klasifikasi udang tenggek dengan bantuan komputer menggunakan pengolahan citra dapat membantu mengklasifikasi jenis udang tenggek yang beracun atau tidak. Teknik data mining dapat dimanfaatkan untuk melakukan klasifikasi udang tenggek berdasarkan warna RGB (red, green, blue) dan tekstur (energy, contrast, correlation, homogeneity). Kelas jenis udang tenggek dibagi menjadi dua, yakni udang tenggek segar yang penangkapannya dengan cara alami (Kelas A) dan udang tenggek beracun yang penangkapannya dengan menggunakan racun (Kelas B). Metode yang digunakan dalam penelitian ini adalah $K-N$ earest Neighbor $(K-N N)$. Sistem klasifikasi ini diharapkan dapat membantu masyarakat dalam memilih udang tenggek yang baik dan aman untuk dikonsumsi. Berdasarkan hasil evaluasi dengan menggunakan metode holdout diperoleh ketelitian rata-rata $63 \%$ dengan ketelitian identifikasi udang tenggek yang beracun sebesar $71.66 \%$, ketelitian identifikasi udang segar alami senilai $60 \%$.
\end{abstract}

Kata kunci: Udang, Klasifikasi, K-Nearest Neighbor, RGB, Tekstur.

\section{PENDAhuluan}

Produksi udang diseluruh dunia saat ini sekitar $77 \%$ produksi udang dihasilkan oleh negara- negara Asia, termasuk Indonesia (Novita, 2016). Menurut data Kementerian Perikanan dan Kelautan, pada tahun 2013 volume ekspor hasil perikanan Indonesia mencapai 802.000 ton dengan nilai US\$
2,6 Miliar. Diantara volume tersebut sebagian besar berasal dari komoditas udang, yaitu mencapai US\$ 997 Juta (Kania dalam Novita, 2016). Indragiri Hilir merupakan salah satu kabupaten di Indonesia yang berada di provinsi Riau yang memiliki kekayaan alam begitu melimpah. Dikelilinginya Indragiri Hilir dengan laut 
sungai maupun parit yang begitu luas menjadikan Indragiri Hilir sebagai salah satu penghasil makanan laut terbesar di Riau. Pada tahun 2016 tingkat pemanfaatan perairan pada sumberdaya penangkapan diperairan laut Kab. INHIL mencapai 41,23 $\%$ dengan perdagangan perikanan antar Kabupaten mencapai 3.889.038 Ton (DKP INHIL, 2016). Udang tenggek (Vanamei) merupakan salah satu makanan laut yang sangat disukai dan diminati masyarakat karna rasa nya yang enak dan sering menjadi menu utama yang ada dirumah makan atau restoran. Udang tenggek biasanya ditangkap dengan cara yang berbeda-beda, yakni ada yang dengan menggunakan penangkapan alami misalnya menggunakan jala (menggunakan umpan yang tidak beracun) dan ada yang penangkapan nya dengan menggunakan racun (racun supaya banyak udang yang didapatkan, seperti decis, tuba dll). Klasifikasi jenis udang tenggek yang beracun jarang sekali bahkan tidak pernah dilakukan di pasaran, sehingga sering kali berdampak bagi pembeli yang mengkonsumsinya seperti tenggorokan kering, sakit perut dan lainlain. Pengklasifikasian udang yang beracun atau tidak yang dilakukan secara manual memberikan hasil klasifikasi yang kurang tepat dan tidak konsisten dikarenakan adanya keteledoran dari manusia dan akan mengalami kesulitan apabila mengklasifikasikan udang dalam jumlah yang cukup banyak.

Perkembangan perangkat keras dan perangkat lunak komputer yang begitu cepat dan didukung konsep datamining berupa klasifikasi pengenalan pola serta teknik-teknik pengolahan citra, maka diharapkan penentuan klasifikasi udang tenggek dengan bantuan komputer dapat direalisasikan oleh karena itu peneliti mengambil penelitian tentang "Sistem Klasifikasi Udang Beracun pada Jenis Udang Tenggek Menggunakan Metode K-Nearest Neighbor". Dengan sistem ini diharapkan penjual maupun pembeli dapat dengan mudah mengklasifikasikan jenis udang tenggek yang beracun ataupun tidak.

\section{TINJAUAN PUSTAKA}

\subsection{Sistem}

Sistem adalah suatu jaringan kerja dari prosedur-prosedur yang saling berhubungan, berkumpul bersama-sama untuk melakukan suatu kegiatan atau untuk menyelesaikan suatu sasaran tertentu ( Syukron, 2015).

\subsection{Klasifikasi}

Klasifikasi adalah proses pengelompokan objek atau pola (pattern) ke dalam kategori (label kelas) tertentu yang telah di definisikan sebelumnya, berdasarkan fitur (atribut) nya (Dougherty dalam Abdullah, 2017). Tugas klasifikasi adalah melakukan prediksi variabel target categorical / diskrit. Klasifikasi pola merupakan area yang penting dalam mesin pembelajaran dan kecerdasan buatan. Area ini telah menjadi bagian integral dalam kebanyakan sistem mesin kec erdasan atau mesin otomatis yang dibangun untuk pengambilan keputusan. Input pada Classification system adalah pattern dan keluarannya adalah kategori sebagaimana Gambar 1 berikut (Abdullah, 2017)

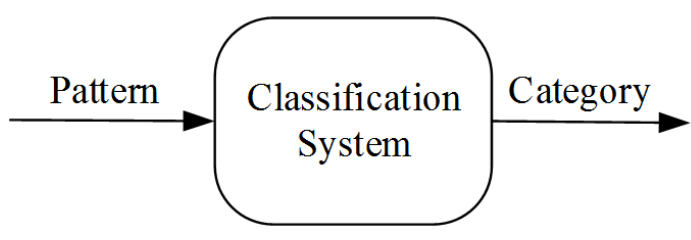

Gambar 1. Diagram blok sistem klasifikasi

\subsection{Citra Digital}

Menurut Kustanto (2017) Citra dapat dikatakan sebagai citra digital jika citra tersebut disimpan dalam format digital (dalam bentuk file). Seperti halnya proses digitisasi dalam bentuk data lain, proses digitisasi pada data citra juga merupakan proses pengubahan suatu bentuk data citra dari yang bersifat analog ke dalam bentuk data digital, yang mana proses ini dapat dilakukan dengan alat bantu, yang salah satunya berupa kamera. Hanya citra digital yang dapat diolah menggunakan komputer. Jenis citra lain jika akan diolah dengan komputer harus diubah dulu menjadi citra digital.

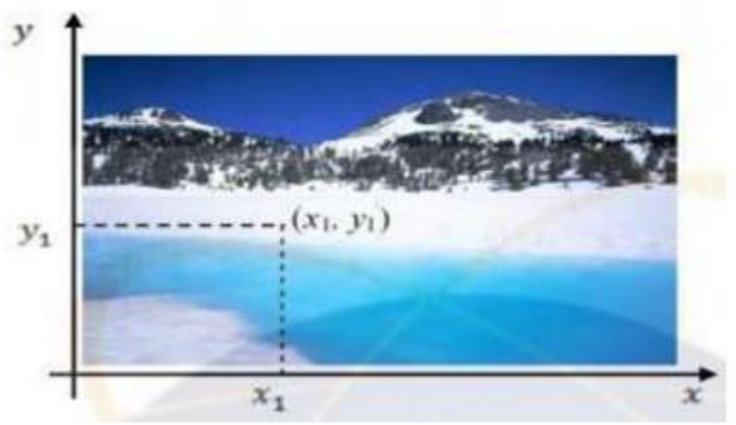

Gambar 2. Citra Digital

Gambar 2 ditampilkan dengan matriks berukuran $\mathrm{N} \times \mathrm{M}$ ( $\mathrm{N}$ menyatakan baris atau tinggi, $M$ menyatakan kolom atau lebar) (Hestiningsih dalam Kustanto, 2017). 


$$
\begin{aligned}
& \text { ISSN: 2620-3332 } \\
& f(x, y)=\left[\begin{array}{ccc}
f(0,0) & f(0,1) & f(0, M-1) \\
f(0,1) & f(1,1) & f(1, M-1) \\
f(N-1.0) & f(N-1,1) & f(N-1, M-1)
\end{array}\right] \\
& \text { Keterangan: } \\
& \mathrm{N}=\text { jumlah baris, } 0=\mathrm{y}=\mathrm{N} 1 \mathrm{M}=\text { jumlah } \\
& \mathrm{L}=\begin{array}{l}
\text { kolom, } 0=\mathrm{x}=\mathrm{M} 1 \\
\text { maksimal warna intensitas } \quad \text { (derajat }
\end{array}
\end{aligned}
$$

\subsection{Pengolahan Citra Digital}

Pengolahan citra digital adalah pemrosesan citra, khususnya dengan menggunakan komputer sehingga citra itu kualitasnya menjadi lebih baik dan menghasilkan informasi nilai untuk tiap-tiap warnanya. Hubungan pengolahan citra dengan computer vision yaitu pengolahan citra merupakan proses awal (preprocessing) pada computer vision (Pradhitya, 2014). Pengolahan citra akan merubah citra yang asalnya kurang baik menjadi citra keluaran yang lebih baik. Dengan demikian, inputan nya merupakan citra dan output nya citra pula, hanya saja citra keluaran akan lebih berkualitas dibandingkan citra asal.

\subsection{Ekstrasi Ciri}

Ekstraksi ciri adalah proses mengambil ciri-ciri yang terdapat pada objek didalam citra untuk mengenali objek tersebut. Ekstraksi ciri merupakan langkah awal dalam melakukan klasifikasi dan interpretasi citra. Proses ini berkaitan dengan kuantisasi karakteristik citra ke dalam sekelompok nilai ciri yang sesuai. Ciri-ciri umum yang digunakan untuk mengenali satu atau beberapa objek di dalam citra adalah ukuran, posisi atau lokasi, dan orientasi atau sudut kemiringan objek terhadap garis acuan yang digunakan (Nurhayati, 2015). Beberapa fitur yang dapat digunakan dalam membedakan objek adalah warna RGB dan tekstur.

Ciri RGB merupakan salah satu ruang warna yang umum digunakan. Ruang warna RGB didasarkan pada konsep dimana warna merupakan hasil kombinasi atau penambahan kuat cahaya primer yaitu red, green dan blue. Sebagian besar spectrum yang terlihat oleh mata manusia dapat direpresentasikan dengan mengkombinasikan antara warna merah, hijau dan biru (RGB) dalam perbandingan intensitas beragam. Namun tidak semua warna yang dapat dilihat oleh mata dapat direpresentasikan oleh ketiga warna dasar ini. Ruang warna RGB memiliki rentang nilai yaitu dari nilai minimum 0 sampai dengan nilai maksimum 255 untuk setiap masingmasing kanal ruang warna. Nilai 0 mengidentifikasikan intensitas gelap dan 255 mengidentifikasikan intensitas terang. Kombinasi antar kanal akan menghasilkan 16.777.216 jenis warna. Gambar 2.4 merupakan RGB color space.

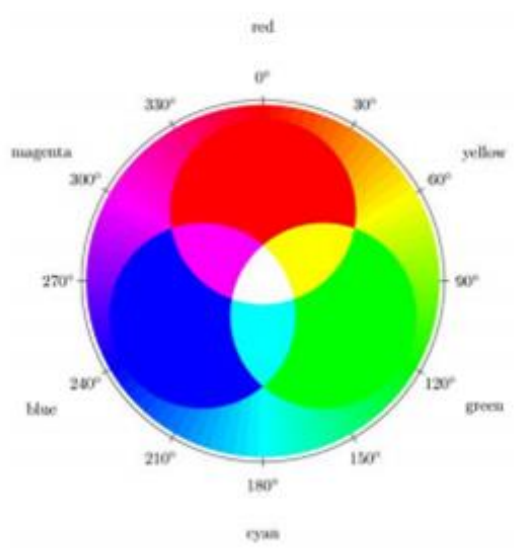

Gambar 3. RGB Color Space

Tekstur dapat didefinisikan sebagai fungsi dari variasi spasial intensitas piksel (nilai keabuan) dalam citra. Berdasarkan strukturnya, tekstur dapat diklasifikasikan dalam dua golongan :

a. Makrostruktur

Tekstur makrostruktur memiliki perulangan pola lokal secara periodik pada suatu daerah citra, biasanya terdapat pada pola-pola buatan manusia dan cenderung mudah untuk direpresentasikan secara matematis.

b. Mikrostruktur

Pada tekstur mikrostruktur, pola-pola lokal dan perulangan tidak terjadi begitu jelas, sehingga tidak mudah untuk memberikan definisi tekstur yang komprehensif.

Contoh gambar berikut ini menunjukkan perbedaan tekstur makrostruktur dan mikrostruktur (atas : makrostruktur ; bawah : mikrostruktur).

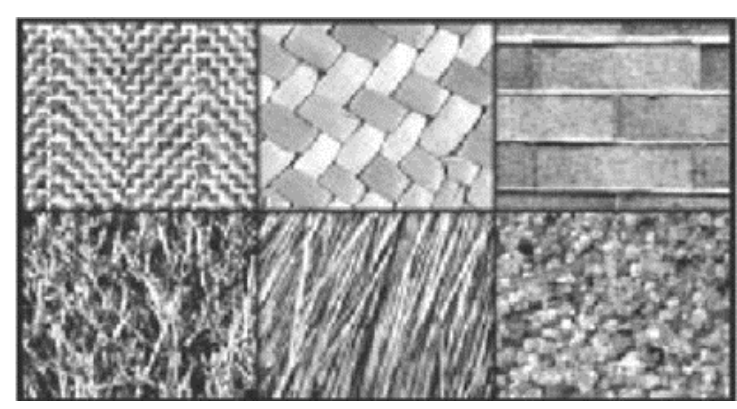

Gambar 4. Contoh Tekstur Visual

\subsection{Data Mining}

Abdillah (2016) Mengatakan Data Mining merupakan proses ekstraksi data 
menjadi informasi yang sebelumnya belum tersampaikan, dengan teknik yang tepat proses data mining akan memberikan hasil yang optimal. Data mining lebih tepat disebut sebagai penambangan pengetahuan dari data, langkah-langkah penting dalam proses penambangan pengetahuan dari data secara umum sebagai berikut :

1. Pembersihan data (data cleaning), yaitu proses menghapus data pengganggu (noise) yang dikatakan tidak konsisten atau tidak diperlukan.

2. Integrasi data (data integration), yaitu menggabungkan berbagai sumber data.

3. Pemilihan data (data selection), yaitu memilih data yang dipilih sesuai kebutuhan analisis.

4. Transformasi data (data transformation), yaitu proses transformasi data ke dalam format untuk diproses dan siap ditambang.

5. Penggalian data (data mining), yaitu menerapkan metode kecerdasan untuk ekstraksi pola.

6. Evaluasi pola (pattern evaluation), yaitu mengidentifikasi pola-pola yang menarik yang merepresentasikan pengetahuan.

7. Penyajian pola (knowledge presentation), yaitu teknik untuk memvisualisasikan pola pengetahuan ke pengguna.

\subsection{K-Nearest Neighbor (K-NN)}

K-Nearest Neighbor (KNN) merupakan metode yang biasa digunakan pada klasifikasi data. Algoritma ini digunakan untuk mengklasifikasikan terhadap objek berdasarkan data pembelajaran yang jaraknya paling dekat dengan objek tersebut. KNN merupakan suatu metode yang menggunakan algoritma supervised dengan hasil dari query instance yang baru diklasifikasikan berdasarkan mayoritas dari kategori pada KNN. Tujuan dari algoritma ini ialah mengklasifikasikan objek baru berdasarkan atribut dan training sample (Larose dalam Simanjuntak, 2017).

untuk menentukan kelas objek yang tidak diketahui cukup dengan menemukan tetangga terdekat objek tersebut. Karena mereka merupakan tetangga berdekatan, maka objek tersebut mirip dengannya dan berada pada kelas yang sama. Keuntungan metode tetangga terdekat adalah mudah untuk diimplementasikan. Metode ini juga dapat memberikan hasil yang cukup baik jika fitur signifikan dipilih secara teliti. Ada beberapa kelemahan nearest neighbour yaitu metode ini agak lambat jika memiliki banyak sample dan $\mathrm{k}-\mathrm{NN}$ sangat sensitif terhadap kehadiran fitur yang tidak relevan.
Fitur yang tidak relevan dapat menyebabkan metode ini gagal (Cunningham dan Delany dalam Abdullah, 2017).

Ilustrasi pada Gambar 5 di bawah ini menunjukkan klasifikasi dari k-NN k=3.

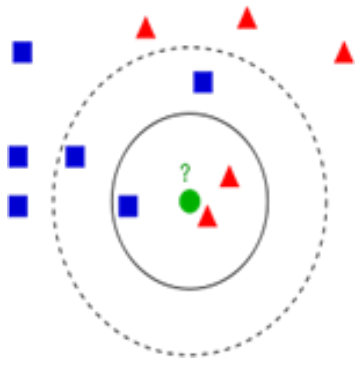

Gambar 5. Klasifikasi K-NN

\section{Metode Pengembangan Sistem}

Pada pengembangan sistem ini dilakukan penentuan udang tenggek melalui pengolahan citranya. Prediksi citra kopra dilakukan pada citra warna 24 bit dengan format Bitmap (BMP) dengan ukuran 640x480. Pada penelitian klasifikasi ini pengambilan citra dilakukan pada perekor udang, bukan perkelompok udang. Ciri pembeda yang digunakan adalah fitur warna RGB yaitu red green blue serta fitur tekstur yaitu contrast, correlation, energy homogeneity. Pada penelitian klasifikasi jenis udang tenggek ini tidak mengukur kadar racun maupun jenis racun yang ada pada udang tenggek.

Citra udang tenggek diambil dengan menggunakan kamera Smartphone xiomi dengan resolusi $13 \mathrm{MP}$ dan tiang penyangga (tripod) untuk pengambilan citra sehinggga jarak akan bernilai sama. yang kemudia citra akan dibagi menjadi dua kelas atau kategori yaitu udang tenggek segar yang penangkapannya dengan cara alami (Kelas A) dan udang beracun karna penangkapannya dengan menggunakan racun (Kelas B). Gambar 6. merupakan bahan dan peralatan (instrument) yang digunakan dalam penelitian.

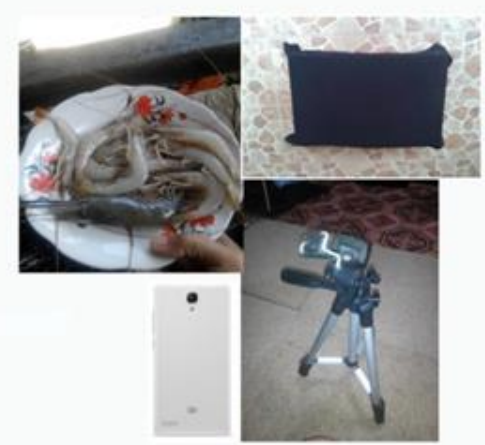

Gambar 6 Instrumen Penangkapan Citra 


\section{IMPLEMENTASI SISTEM}

Sistem dibagi menjadi dua buah fase sistem yaitu fase pembentukan kelas yang ditujukan untuk membentuk kelas klasifikas udang tenggek dalam rangka pelatihan sistem sebelum dilakukan klasifikasi terhadap suatu citra uji dan fase sistem klasifikasi yang akan mengidentifikasi suatu citra udang tenggek yang belum diketahu label kelasnya.

\subsection{Fase Sistem Pembentukan Kelas}

Dalam fase pembentuk kelas terdapat beberapa tombol yang dapat digunakan oleh developer untuk melakukan kegiatan pelatihan terhadap sistem dengan membentuk kelas-kelas klasifikasi menggunakan file citra sampel. Tampilan interfase fase pembentukan kelas dapat dilihat pada Gambar 7.

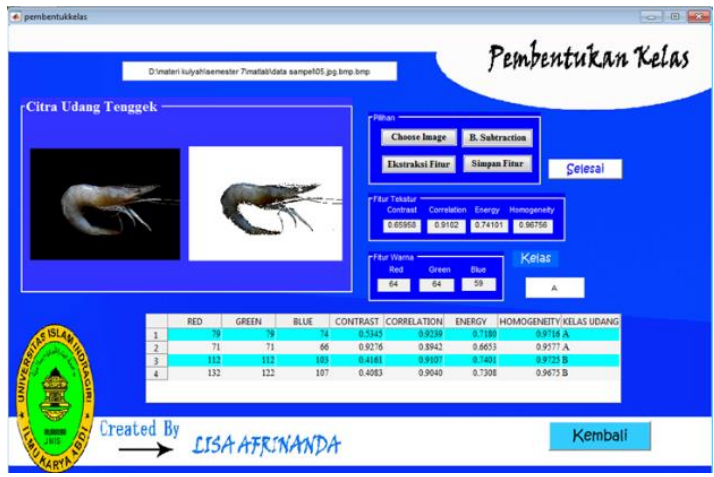

Gambar 7 Antarmuka Klasifikasi

\subsection{Fase Sistem Klasifikasi}

Antarmuka klasifikasi bertujuan untuk melakukan klasifikasi atau pendeteksian terhadap suatu citra uji. Terdapat beberapa tombol pada fase klasifikasi yang dapat digunakan oleh user untuk melakukan kegiatan klasifikasi terhadap suatu data uji (citra query). Tampilan interfase fase klasifikasi dapat dilihat pada Gambar 8.

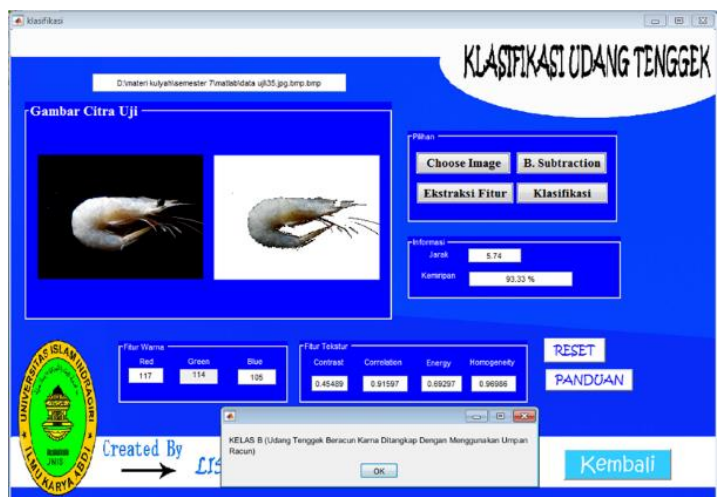

Gambar 8 Antarmuka Klasifikasi

\section{HASIL DAN EVALUASI}

Pengujian atau evaluasi dilakukan untuk mengetahui sejauh mana kemampuan sistem dalam melakukan klasifikasi udang tenggek. Pengujian dilakukan dengan beberapa bagian yaitu dengan tetangga terdekat $\mathrm{K}=1, \mathrm{~K}=3, \mathrm{~K}=5$ dan $K=7$. Pengujian dilakukan dengan teknik validasi holdout dimana digunakan data citra udang tenggek sebanyak 60 citra sebagai sampel dan 30 citra sebagai data uji.

Tabel 1 Matriks Konfusi Pengujian Pada k = 1

\begin{tabular}{|c|c|c|c|}
\hline \multicolumn{2}{|c|}{$f_{i j}$} & \multicolumn{2}{c|}{$\begin{array}{c}\text { Kelas Hasil } \\
\text { Klasifikasi }\end{array}$} \\
\cline { 3 - 4 } \multicolumn{2}{|c|}{} & Kelas A & Kelas B \\
\hline \multirow{2}{*}{ Kelas Asli } & Kelas A & 10 & 5 \\
\cline { 2 - 4 } & Kelas B & 3 & 12 \\
\hline
\end{tabular}

Dari table 1 di atas diketahui bahwa klasifikasi yang dilakukan menggunakan metode k-Nearest Neighbor pada $\mathrm{k}=1$ dengan data uji sebanyak 30 citra, citra uji yang diklasifikasikan secara benar oleh sistem sebanyak 22 citra uji, sedangkan sisanya sebanyak 8 citra uji diklasifikasikan salah oleh sistem. Dengan demikian dapat diketahui bahwa akurasi yang diperoleh sebesar 73, $33 \%$.

Tabel 2 Matriks Konfusi Pengujian Pada $k=3$

\begin{tabular}{|c|c|c|c|}
\hline \multicolumn{2}{|c|}{$f_{i j}$} & \multicolumn{2}{c|}{ Kelas Hasil Klasifikasi } \\
\cline { 3 - 4 } & & Kelas A & Kelas B \\
\hline \multirow{2}{*}{ Kelas Asli } & Kelas A & 10 & 5 \\
\cline { 2 - 4 } & Kelas B & 4 & 11 \\
\hline
\end{tabular}

Dari tabel 2 di atas diketahui bahwa klasifikasi yang dilakukan menggunakan metode k-Nearest Neighbor pada $\mathrm{k}=3$ dengan data uji sebanyak 30 citra, citra uji yang diklasifikasikan secara benar oleh sistem sebanyak 21 citra uji, sedangkan sisanya sebanyak 9 citra uji diklasifikasikan salah oleh sistem. Dengan demikian dapat diketahui bahwa akurasi yang diperoleh sebesar $70 \%$.

Tabel 3 Matriks Konfusi Penqujian Pada k = 5

\begin{tabular}{|c|c|c|c|}
\hline \multicolumn{2}{|c|}{$f_{i j}$} & \multicolumn{2}{c|}{ Kelas Hasil Klasifikasi } \\
\cline { 3 - 4 } & Kelas A & Kelas A & Kelas B \\
\hline \multirow{2}{*}{ Kelas Asli } & Kelas B & 4 & 5 \\
\cline { 2 - 4 } & & 11 \\
\hline
\end{tabular}

Dari tabel 3 di atas diketahui bahwa klasifikasi yang dilakukan menggunakan metode k-Nearest Neighbor pada $\mathrm{k}=5$ dengan data uji sebanyak 30 citra, citra uji yang diklasifikasikan secara benar oleh sistem sebanyak 21 citra uji, sedangkan sisanya sebanyak 9 citra uji diklasifikasikan salah oleh sistem. Dengan demikian dapat diketahui bahwa akurasi yang diperoleh sebesar $70 \%$. 
Tabel 4 Matriks Konfusi Pengujian Pada $k=7$

\begin{tabular}{|c|c|c|c|}
\hline \multirow{2}{*}{\multicolumn{2}{|c|}{$f_{i j}$}} & \multicolumn{2}{|c|}{ Kelas Hasil Klasifikasi } \\
\hline & & Kelas A & Kelas B \\
\hline \multirow{2}{*}{ Kelas Asli } & Kelas A & 9 & 6 \\
\hline & Kelas B & 6 & 9 \\
\hline
\end{tabular}

Dari tabel 4 di atas diketahui bahwa klasifikasi yang dilakukan menggunakan metode k-Nearest Neighbor pada $k=7$ dengan data uji sebanyak 30 citra, citra uji yang diklasifikasikan secara benar oleh sistem sebanyak 18 citra uji, sedangkan sisanya sebanyak 12 citra uji diklasifikasikan salah oleh sistem. Dengan demikian dapat diketahui bahwa akurasi yang diperoleh sebesar $60 \%$.

Selanjutnya pada Gambar 9 diperlihatkan beberapa contoh hasil klasifikasi udang tenggek yang dilakukan secara benar atau berhasil diklasifikasikan oleh sistem.

$\begin{array}{ll}\text { Nama Kelas : Kelas A } & : 2.83 \\ \text { Jarak } & : 96.98 \% \\ \text { Kemiripan }\end{array}$

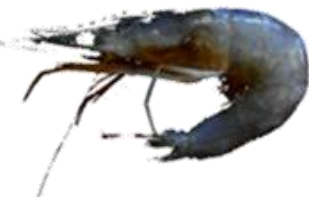

Nama Kelas : Kelas B

Jarak : 2,45

Kemiripan : $95.84 \%$

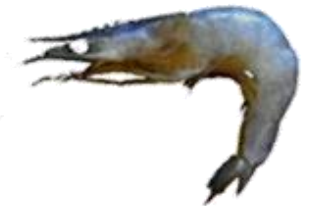

Gambar 9 Contoh Udang Tenggek Yang Diklasifikasikan Secara Benar

Kemudian pada Gambar 10 akan dilakukan pengujian terhadap sistem penolakan (rejection) bila mana kemiripan yang diperoleh dari citra query kurang dari nilai ambang / threshold yakni sebesar 50 $\%$.

$\begin{array}{ll}\text { Nama Kelas } & : \text { DITOLAK } \\ \text { Jarak } & : 93,01 \\ \text { Kemiripan } & : 25 \%\end{array}$

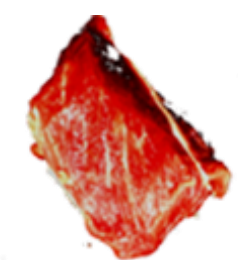

Gambar 10 Contoh Objek Ditolak Untuk Diklasifikasikan

Berdasarkan gambar 10, diketahui bahwa apabila kemiripan yang diperoleh dari citra uji (daging) kurang dari 50 \%, maka sistem klasifikasi udang tenggek akan melakukan penolakan (rejection). Dengan demikian dapat ditarik kesimpulan bahwa sistem yang dibangun mampu untuk mengenali udang tenggek saja, sedangkan jenis lain (contohnya daging babi) tidak dikenali oleh sistem, karena diluar dari pengetahuan sistem

\section{Kesimpulan Dan Saran}

Membangun sistem klasifikasi udang tenggek yang alami dan yang beracun menggunakan metode k-nearest neighbor berdasarkan fitur warna dan tekstur. Hal pertama yang harus dilakukan adalah pengumpulan data yang akan digunakan untuk dijadikan data sampel dan data uji. Berdasarkan metode Holdout dan akurasi matrix confusion dengan tetangga terdekat $\mathrm{K}=1, \mathrm{~K}=3, \mathrm{~K}=5, \mathrm{~K}=7$ didapatkan ketelitian identifikasi udang tenggek yang beracun sebesar $71.66 \%$, ketelitian identifikasi udang segar alami senilai $60 \%$. Secara umum sistem klasifikasi udang tengggek ini memiliki ketelitian $63 \%$. Untuk penelitian selanjutnya diharapkan pada saat pengambilan citra gambar tidak lagi menggunakan citra latar (background) dan dapat dikembangakan pada device android

\section{DAFTAR PUSTAKA}

[1] Abdillah G. dkk. 2016. Penerapan Data Mining Pemakaian Air Pelanggan Untuk Menentukan Klasifikasi Potensi Pemakaian Air Pelanggan Barudi Pdam Tirta Raharja Menggunakan Algoritma K-Means. Seminar Nasional Teknologi Informasi dan Komunikasi 2016 (SENTIKA 2016). ISSN: 2089-9815

[2] Kustanto, 2017, Computing Grayscale Of Face Detection Menggunakan Metode Sobel Dan Laplacian Of Gaussian. Jurnal Antivirus, Vol. 11 No. 1, P-ISSN: 19785232 E-ISSN: 2527-337X

[3] Nurhayati O.D, 2015, Sistem Analisis Tekstur Secara Statistik Orde Pertama Untuk Mengenali Jenis Telur Ayam Biasa Dan Telur Ayam Omega-3. JURNAL SISTEM KOMPUTER. Vol. 5 No 2, ISSN : 2087-4685, e-ISSN: 2252-3456

[4] Pradhitya Rio.2014. Pembangunan Aplikasi Deteksi dan TrackingWarna Virtual Drawing Menggunakan Algoritma Color Filtering. Jurnal Ilmiah Komputer dan Informatika (KOMPUTA). Volume 2 No 1, ISSN:2089-9033

[5] Simanjuntak T.H, dkk. 2017. Implementasi Modified K-Nearest Neighbor Dengan Otomatisasi Nilai K Pada Pengklasifikasian Penyakit Tanaman Kedelai. Jurnal Pengembangan Teknologi Informasi dan IImu Komputer.Vol 1 No 2, ISSN: 2548964

[6] Syukron Akhmad dkk, 2015, 
Perancangan Sistem Informasi Rawat Jalan Berbasis Web Pada Puskesmas Winong, Jurnal Bianglala Informatika. Vol 3 No 1, ISSN: 2338-9761. 